\title{
ANCIENT TUNISIAN MOSQUES: MORPHOLOGICAL KNOWLEDGE AND CLASSIFICATION
}

\author{
I. CHERIF \& N. ALLANI BOUHOULA \\ National School of Architecture and Urbanism, University of Carthage, Tunis, Tunisia.
}

\begin{abstract}
This article is attempting to identify and understand the morphological characteristics related to the spatial structure of the ancient Tunisian mosques. The interest in these architectural objects made us think that the homogeneity of what is commonly called 'ancient Tunisian mosque' is not a unique model but can have a variety of recognizable morphological classes. Through a morphological analysis of 22 specimens, we were able to identify their distinctive features by determining their identity and their morphological structure. Thus we identified classes of specimens and classes of segments based on their shape and position. The linking of the intrinsic morphological knowledge with other fields of knowledge may provide us extrinsic explanations which in turn allowed us to identify the relationship that may exist between these architectural objects and their physical, temporal and cultural context.
\end{abstract}

Keywords: ancient mosques, form, morphological identity, position, spatial structure.

\section{INTRODUCTION}

In Tunisia, and throughout the countries marked by Islam, the architecture of mosques has evolved with the contributions of civilizations and cultures over the centuries. Today, these countries have a rich heritage that has been the subject of considerable scientific studies [1-3].

Currently, new mosques are often being built. Dictated by the modern age, this religious equipment undergoes transformations and various changes which confer to them their own morphological identity [4].

On the one hand, architects attempt to replicate the great styles or try to recycle the elements considered as the most meaningful and the most recognizable in the mosque's architecture. On the other hand, new trends have emerged and sometimes break the stereotypical model that has often been attributed to the mosque [5]. Therefore, the architecture of new mosques has been the subject of a certain amount of controversial debates. In 2008, and in order to preserve the architectural features of Tunisian mosques, the Ministry of Religious Affairs developed guidelines for the design of new mosques. Certainly, this initiative shows a desire to preserve the Tunisian achievements; nevertheless, it does not result from a reliable scientific research. In this article we propose to identify the morphological structure (spatial structure) of 22 ancient Tunisian mosques and their specific features; this is why we used the method of morphological analysis which allows us to explore the inter-structure of forms and the organization of the man-made objects. So we assume that the spatial structure of ancient Tunisian mosques does not present a single model but a variety of morphological classes resulting in an intelligible classification. 


\section{GENERAL CONTEXT OF STUDY}

\subsection{The mosque and its roles}

The word 'Mosque' is derived from the Arabic word 'Masjid' (دجسم) which is composed of the prefix of place ' $m$ ' (p) and the root of the word 'Sajada' (دّ) (2) that refers to the act of prostrating by putting the forehead to the ground. So a mosque refers to a place for inclination conformed to the attitude of prayer. Gradually, we attribute the term Masjid for small mosque, or the neighbourhood or local mosque, where people gather daily for the five-time communal prayers; and the term 'masjid Djami' or 'Al-Jami' means the main or the great mosque where the 'Imam' conducts the Friday prayer and addresses a speech 'Khutbah' to Muslim community [6].

Although no architectural recommendation is mentioned in the Quran, the mosque as a worship place is mentioned as 'in houses which Allah hath allowed to be exalted and that His name shall be remembered therein. Therein do offer praise to Him at morn and evening'. [7]. According to Ulya vogt-Gôknil [8] first mosques are characterized by an indecisive evolution that proves the absence of obligatory rules. Arab conquerors were nomads and had no architectural tradition and no experience in building. Thus, despite the absence of architectural indication for the design of this prayer space, the mosque, which initially responded to a practical concern, saw its architecture become more complex over the centuries.

Given the importance of this place, innumerable human and material resources are attributed to the construction of the mosque. In fact, the mosque has always been a structuring element in the ancient Islamic city and considered as the central core of the city towards which everything converges and from which everything flows back. At the hour of prayer, the faithful had the opportunity to meet, to exchange information and to discuss and focus on the common problems. In addition to its spiritual function (prayer and teaching of religions), the mosque was also a place of political government, military command, a tribunal, a pole of media coverage and a medium to consult with the population. So it was a privileged place where decisions, information and knowledge were diffused and where politics and religion are closely entangled.

\subsection{Tunisian mosques, stylistic trends, evolution and principal components}

Since the 6th century, mosques have been built around the globe. While there are many different types of mosque architecture, influenced by regions' climate and local architectural features, three basic forms of plan can be defined: the Arab plan, the person plan and the ottoman plan.

The prevalent model in Tunisia reminds that of the Arab plan also named the hypostyle mosque. It is characterized by a prayer room juxtaposed by a courtyard that is surrounded by a series of arches. The minaret is square and the 'minbar' is in wood.

The Great Mosque of Kairouan is the first mosque built in Ifriqiya under the Umayyad dynasty and has aroused the interest of several researchers $[9,10]$.

It played an important role in the expansion of Islam in North Africa and Spain. Characterized by hypostyle plan, it was built by Okba Ibn Nafi in 670. Then it was rebuilt under the Aghlabids (9th century). The current state of the mosque can be traced back to their reign. The great mosque of Kairouan served as a model for the construction of subsequent mosques throughout the region. And with the advent of the Ottomans in 1574, the art of building while performing innovations was perfectly adapted to older traditional techniques and regional materials that used to be employed a long time ago. Builders, while adopting some new processes, have continued to practise techniques inherited from past times [11] (Fig. 1). 


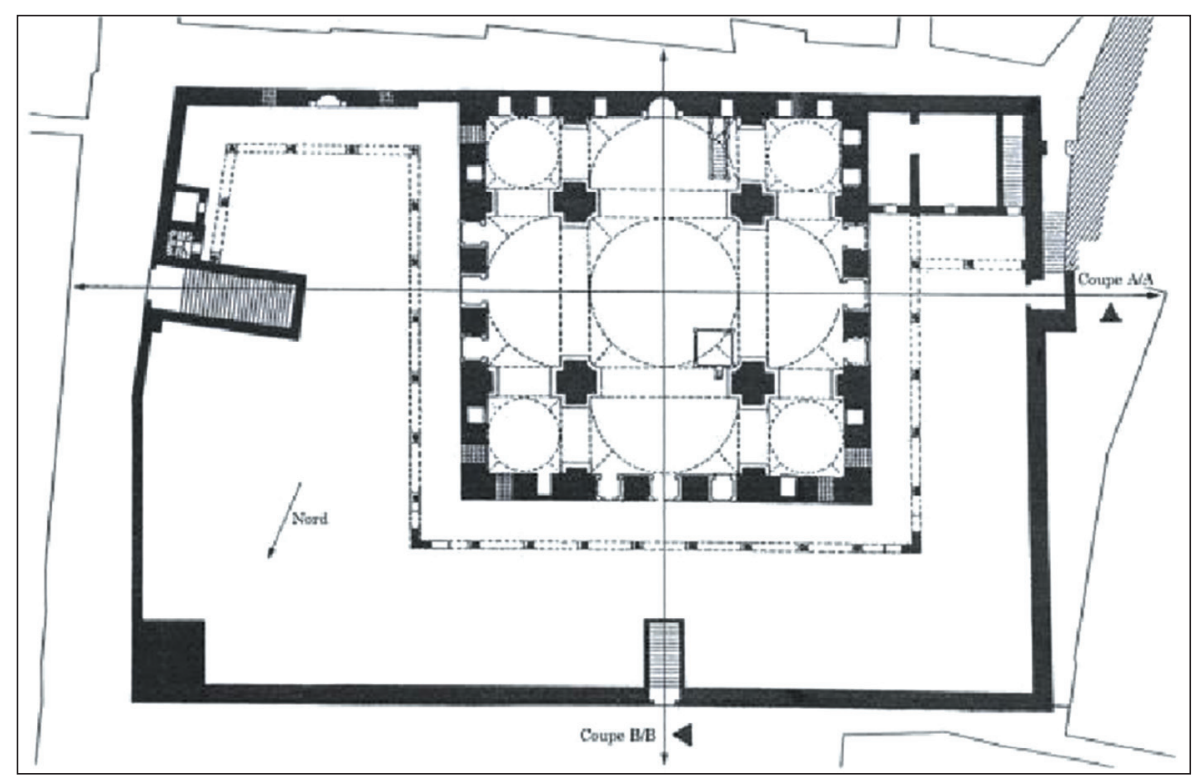

Figure 1: The Plan of Muhamed Bey Mosque. (Source: National Institute of Tunis's Heritage)

Thus, some changes have been made to the architecture of mosques, but without breaking the local architectural traditions. The Ottoman contribution was limited to the addition of architectural or decorative elements; no mosque was built according to the Turkish prototype. Only one attempt was observed in the mosque Mohammed Al-Bey Mouradi, which remained unfinished (having no minaret) (Fig. 2).

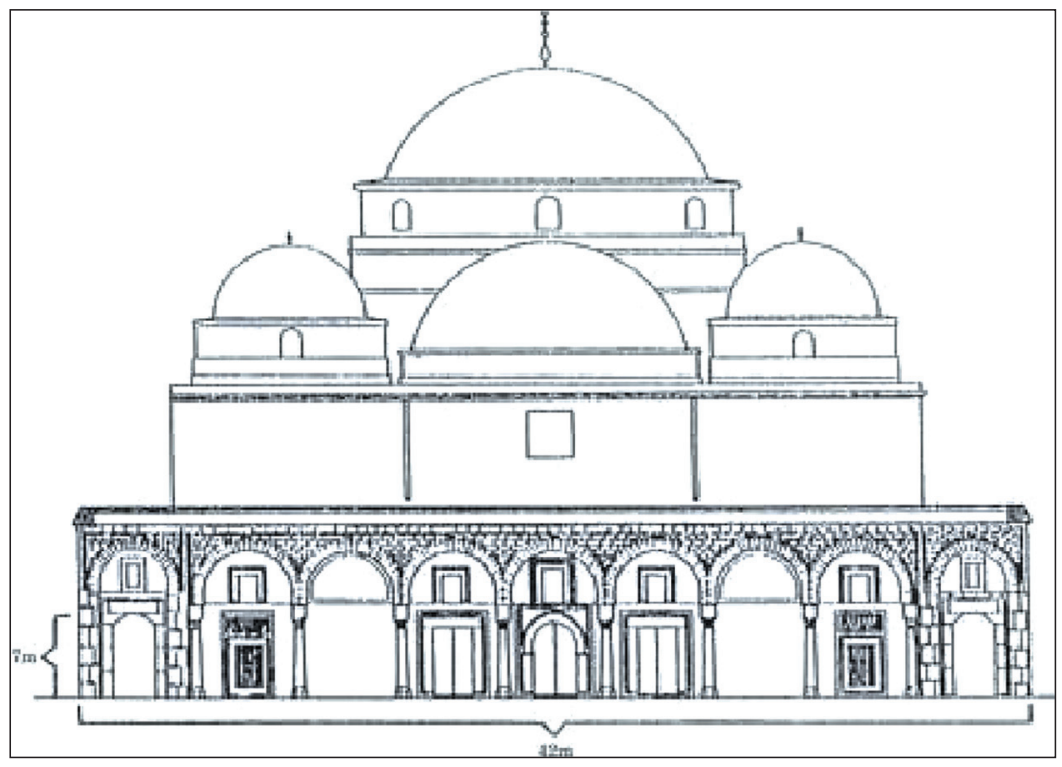

Figure 2: Muhamed Bey Mosque - the facade of the prayer hall. (Source: National Institute of Tunis's Heritage) 
Among the Ottoman contributions in the architecture of mosque in Tunisia, we can mention the construction of octagonal minaret, which signals the belonging of the mosque to the Hanafi rite which has become the rite of the state at that time. Also, the 'minbar' is constructed and the court juxtaposes the prayer room of more than one side.

Other architectural influences were introduced by the Muslim refugees from Spain (Andalusia) who emigrated in successive waves to Tunisia. The latest and most important has occurred in 1609; the Moriscos played an important role in the growth of architectural and decorative activities. They played a considerable role in developing the production of tiles, bricks and ceramic wall tiling [11].

The main components of mosque in Tunisia are:

- The prayer hall: it is a covered space, intended to receive the faithful for the communal prayer. The orientation is the only directive required for this place. It must be oriented to the 'qibla' (direction to Mecca). The prayer hall includes some elements such as the 'Mihrab' (a niche indicating the direction to which faithful must turn towards for praying), the 'Minbar' (a pulpit that takes the form of a flight of steps. It is used by the Imam to communicate his sermon 'khutba' for faithful during Friday prayers.), and the 'maqsurah' (an enclosure or wooden screen which delimited a private area reserved to the sovereign for his prayer).

- The gallery: arcaded porticoes; it closes in one or more than one side of the courtyard and it allows the passage from covered area to open space.

- The courtyard: it is an uncovered area; it is a transient space between the outside and the prayer hall. It allows extension of prayer's area, especially in warm periods.

- The ablutions room: in this space the Muslim can be made to undergo a state of ritual purity before performing his prayer. It may be at the entry or in front of the building. A fountain placed in the middle of the courtyard can also be used for ablution.

- Minaret: it is a tower used to call the faithful to prayer five times a day by a 'muezzin'. It also marks the location of the mosque in the agglomeration and it indicates the presence of Islam in the city.

Some other components were introduced in ottoman period:

- The 'mahfil': a balcony inside the prayer hall and in front of 'Mihrab', used by the 'muezzin' or the 'muarif' to reread the Friday prayers and to sing in chorus the invocations and supplications, and it is also used by important personalities to pray.

- The 'khatma': a raised wooden pulpit used for Quranic readings and it contains a box to place the Quran.

- The 'turba': a small building closely integrated into the mosque. It contains the tomb of the mosque's founder.

\section{MORPHOLOGICAL ANALYSIS: STUDY OF THE SPATIAL STRUCTURE}

\subsection{Considerations}

To properly conduct this study we chose a corpus of study which is representative, homogeneous and manageable. In fact, all the specimens in the collection have the same nominal identity and belong to the same kind of object. They are part of the same geographical area. Also the corpus includes 22 specimens, which is a sufficient number to properly conduct this study. 


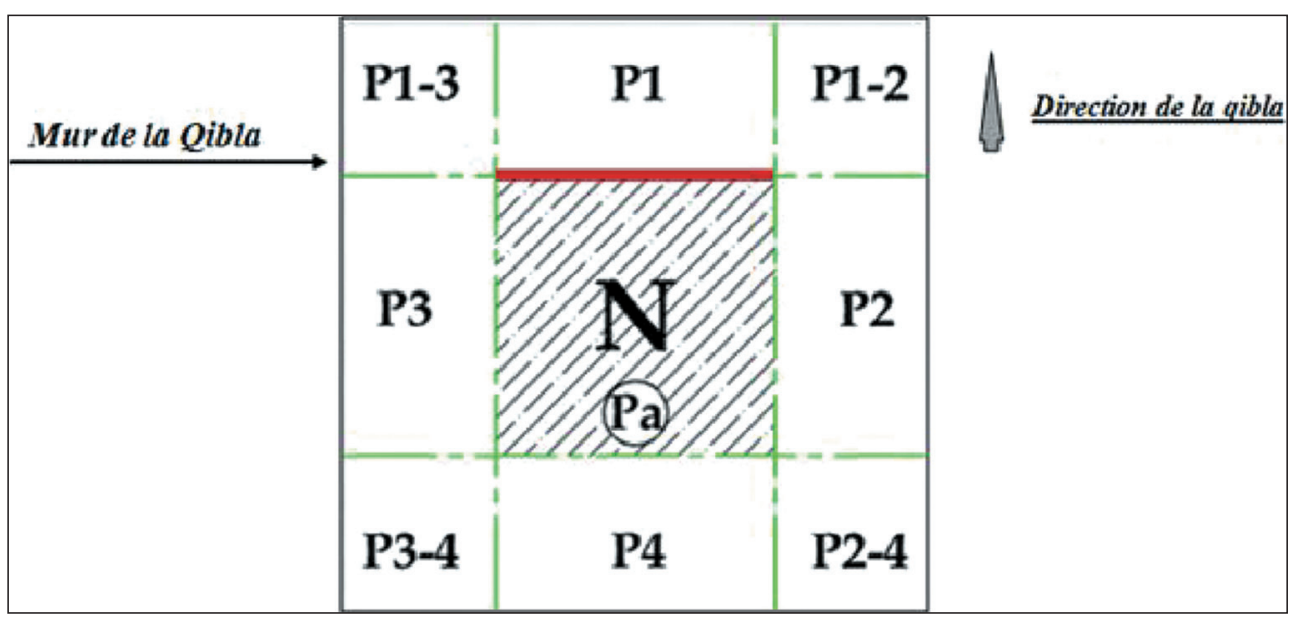

Figure 3: Positions of peripherals Px.

- All specimens ' $\mathrm{S}$ ' are positioned; the wall of the 'qibla' is placed horizontally and the 'qibla' is directed upward.

- $\quad$ Each specimen of the collection possesses a main element (the central core N) which is surrounded by set of peripherals Px.

- Peripherals Px occupy nine positions which are grouped into three categories based on their positions relative to the central core (Fig. 3):

- Peripherals Pc (P1, P2, P3 and P4): their positions are on the side of the central core N.

- Peripherals Pi (P1-2, P2-4, P3-4, and P1-3): their positions are intermediate and intersect the positions of type $\mathrm{C}$.

- Peripherals $\mathrm{Pa}(\mathrm{Pa})$ : they are inside the delimitation area of the central core $\mathrm{N}$

\subsection{Hypothesis}

For each specimen in the collection, we consider that there is a central core N, which makes unity and homogeneity of forms, and a set of peripherals Px which are located in relation with the central core $\mathrm{N}$. We suppose that the position of peripherals Px in relation to the central core $\mathrm{N}$ is meaningful.

\subsection{Results and interpretations}

The central core $\mathrm{N}$ is the main body of the mosque; it is a covered and a dominant element, identifiable by its dominance and the importance of its proportions in relation to other entities. It is the prayer hall.

Peripherals Px constitute the rest of the elements that make up the spatial structure of the mosque. We find that each specimen has a spatial structure constituted by the central core $\mathrm{N}$ and a number $n$ of peripheral Px. 


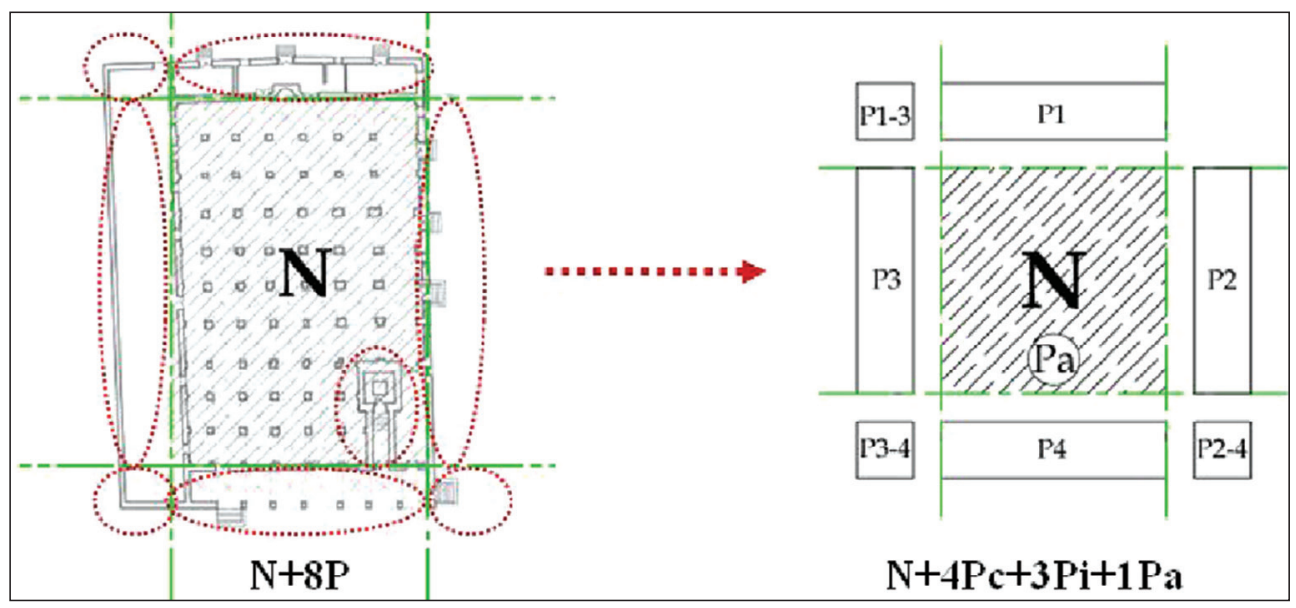

Figure 4: Delimitation of the central core $\mathrm{N}$, determination of peripheral Px and qualification of their positions (specimen S15).

This number $n$ varies from 1 to 9 , depending on the number of positions which peripherals can occupy. So we can say that the spatial structure of the mosque relative to the number of peripherals Px is

$$
\mathrm{N}+n \mathrm{P} \text { with } 1 \leq \mathrm{n} \leq 9
$$

The focus on the qualification of the positions of peripherals Px has allowed us to deduce the spatial structure of the mosque relative to the position of peripherals Px (Fig. 4):

$$
\mathrm{N}+\mathrm{xPc}+\mathrm{yPi}+\mathrm{zPa} \text { with } 0 \leq \mathrm{x} \leq 4 \text { and } 0 \leq \mathrm{y} \leq 4 \text { and } 0 \leq \mathrm{z} \leq 1
$$

So for the mosque, there are different scenarios for the morphological structure; Table 1 identifies the different possible combinations of $\mathrm{Pc}, \mathrm{Pi}$ and $\mathrm{Pa}$. The models found in our collection are marked in colour. The object of our study includes $26 \%$ of all possible morphological structures.

\begin{tabular}{|c|c|c|c|c|c|c|}
\hline & & & & $x \mathrm{Pc}$ & & \\
\hline$y \mathbf{P i}$ & $z \mathbf{P a}$ & 0 & 1 & 2 & 3 & 4 \\
\hline 0 & 0 & $\mathrm{~N}$ & $\mathrm{~N}+1 \mathrm{Pc}$ & $\mathrm{N}+2 \mathrm{Pc}$ & $\mathrm{N}+3 \mathrm{Pc}$ & $\mathrm{N}+4 \mathrm{Pc}$ \\
\hline & 1 & $\mathrm{~N}+1 \mathrm{~Pa}$ & $\mathrm{~N}+1 \mathrm{Pc}+1 \mathrm{~Pa}$ & $\mathrm{~N}+2 \mathrm{Pc}+1 \mathrm{~Pa}$ & $\mathrm{~N}+3 \mathrm{Pc}+1 \mathrm{~Pa}$ & $\mathrm{~N}+4 \mathrm{Pc}+1 \mathrm{~Pa}$ \\
\hline 1 & 0 & $\mathrm{~N}+1 \mathrm{Pi}$ & $\mathrm{N}+1 \mathrm{Pc}+1 \mathrm{Pi}$ & $\mathrm{N}+2 \mathrm{Pc}+1 \mathrm{Pi}$ & $\mathrm{N}+3 \mathrm{Pc}+1 \mathrm{Pi}$ & $\mathrm{N}+4 \mathrm{Pc}+1 \mathrm{Pi}$ \\
\hline & 1 & $\mathrm{~N}+1 \mathrm{Pi}+1 \mathrm{~Pa}$ & $\mathrm{~N}+1 \mathrm{Pc}+1 \mathrm{Pi}+1 \mathrm{~Pa}$ & $\mathrm{~N}+2 \mathrm{Pc}+1 \mathrm{Pi}+1 \mathrm{~Pa}$ & $\mathrm{~N}+3 \mathrm{Pc}+1 \mathrm{Pi}+1 \mathrm{~Pa}$ & $\mathrm{~N}+4 \mathrm{Pc}+1 \mathrm{Pi}+1 \mathrm{~Pa}$ \\
\hline 2 & 0 & $\mathrm{~N}+2 \mathrm{Pi}$ & $\mathrm{N}+1 \mathrm{Pc}+2 \mathrm{Pi}$ & $\mathrm{N}+2 \mathrm{Pc}+2 \mathrm{Pi}$ & $\mathrm{N}+3 \mathrm{Pc}+2 \mathrm{Pi}$ & $\mathrm{N}+4 \mathrm{Pc}+2 \mathrm{Pi}$ \\
\hline & 1 & $\mathrm{~N}+2 \mathrm{Pi}+1 \mathrm{~Pa}$ & $\mathrm{~N}+1 \mathrm{Pc}+2 \mathrm{Pi}+1 \mathrm{~Pa}$ & $\mathrm{~N}+2 \mathrm{Pc}+2 \mathrm{Pi}+1 \mathrm{~Pa}$ & $\mathrm{~N}+3 \mathrm{Pc}+2 \mathrm{Pi}+1 \mathrm{~Pa}$ & $\mathrm{~N}+4 \mathrm{Pc}+2 \mathrm{Pi}+1 \mathrm{~Pa}$ \\
\hline 3 & 0 & $\mathrm{~N}+3 \mathrm{Pi}$ & $\mathrm{N}+1 \mathrm{Pc}+3 \mathrm{Pi}$ & $\mathrm{N}+2 \mathrm{Pc}+3 \mathrm{Pi}$ & $\mathrm{N}+3 \mathrm{Pc}+3 \mathrm{Pi}$ & $\mathrm{N}+4 \mathrm{Pc}+3 \mathrm{Pi}$ \\
\hline & 1 & $\mathrm{~N}+3 \mathrm{Pi}+1 \mathrm{~Pa}$ & $\mathrm{~N}+1 \mathrm{Pc}+3 \mathrm{Pi}+1 \mathrm{~Pa}$ & $\mathrm{~N}+2 \mathrm{Pc}+3 \mathrm{Pi}+1 \mathrm{~Pa}$ & $\mathrm{~N}+3 \mathrm{Pc}+3 \mathrm{Pi}+1 \mathrm{~Pa}$ & $\mathrm{~N}+4 \mathrm{Pc}+3 \mathrm{Pi}+1 \mathrm{~Pa}$ \\
\hline 4 & 0 & $\mathrm{~N}+4 \mathrm{Pi}$ & $\mathrm{N}+1 \mathrm{Pc}+4 \mathrm{Pi}$ & $\mathrm{N}+2 \mathrm{Pc}+4 \mathrm{Pi}$ & $\mathrm{N}+3 \mathrm{Pc}+4 \mathrm{Pi}$ & $\mathrm{N}+4 \mathrm{Pc}+4 \mathrm{Pi}$ \\
\hline & 1 & $\mathrm{~N}+4 \mathrm{Pi}+1 \mathrm{~Pa}$ & $\mathrm{~N}+1 \mathrm{Pc}+4 \mathrm{Pi}+1 \mathrm{~Pa}$ & $\mathrm{~N}+2 \mathrm{Pc}+4 \mathrm{Pi}+1 \mathrm{~Pa}$ & $\mathrm{~N}+3 \mathrm{Pc}+4 \mathrm{Pi}+1 \mathrm{~Pa}$ & $\mathrm{~N}+4 \mathrm{Pc}+4 \mathrm{Pi}+1 \mathrm{~Pa}$ \\
\hline
\end{tabular}

Table 1: Scenario relating to structural models. 


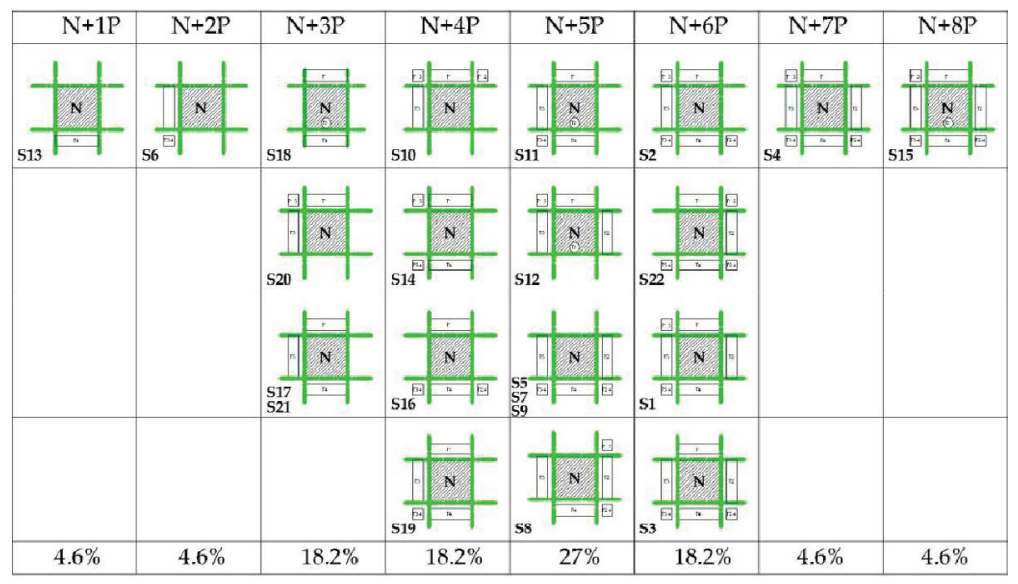

Table 2: Spatial configurations of structural models in the collection.

The study of the position of peripherals Px revealed a combinational system of the spatial structure relative to the mosque. By comparing structural models with spatial configurations, we note that a structural model can contain several spatial configurations. Indeed, the number of peripherals Px is a point of convergence between the specimens and the positions make diversity of spatial structures. Spatial structures converge towards the same structure model while presenting spatial conformations specific to the class to which they belong (Table 2).

Peripherals Px represents a set composed elements which can be a subject to a morphological segmentation. Using morphological analysis allows us to understand and to identify the parts in the whole and the whole in the parts.

The principle of segmentation or decomposition is tracking obvious discontinuities. These discontinuities are a perceptible means of delimitation between adjacent segments. Once the decomposition has been established, the observation by comparing segments of all units allows identifying patterns and/or variations. On this basis, the descriptor of homology chosen should ensure a bijective corresponding relationship between one segment and another segment and also among each segment of the various peripherals. In our article, we specify that the equivalence ratio between the segments is based on the segment of conformation supplemented by the function (Fig. 5).

The classificatory study of homologous segments based on the shape and the position revealed a plastic and positional diversity.

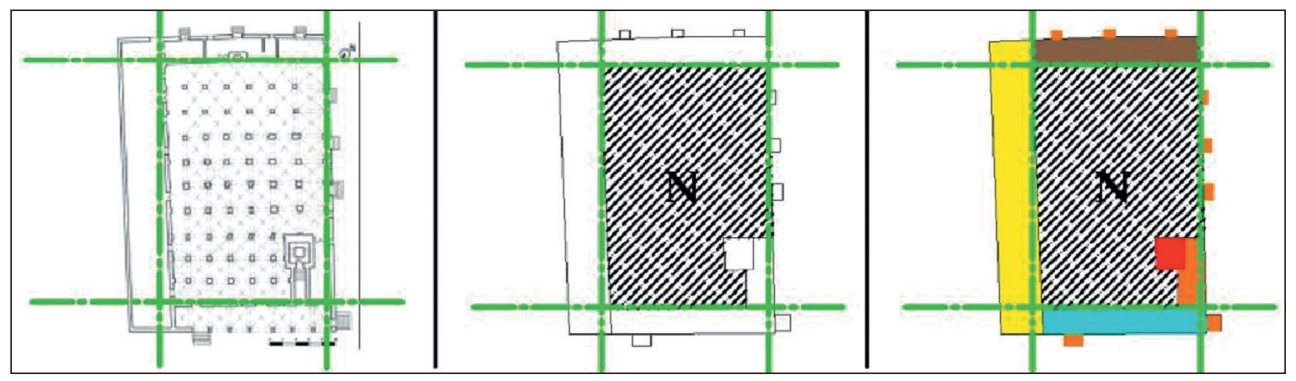

Figure 5: Morphological segmentation Peripheral Px (specimen S15). 


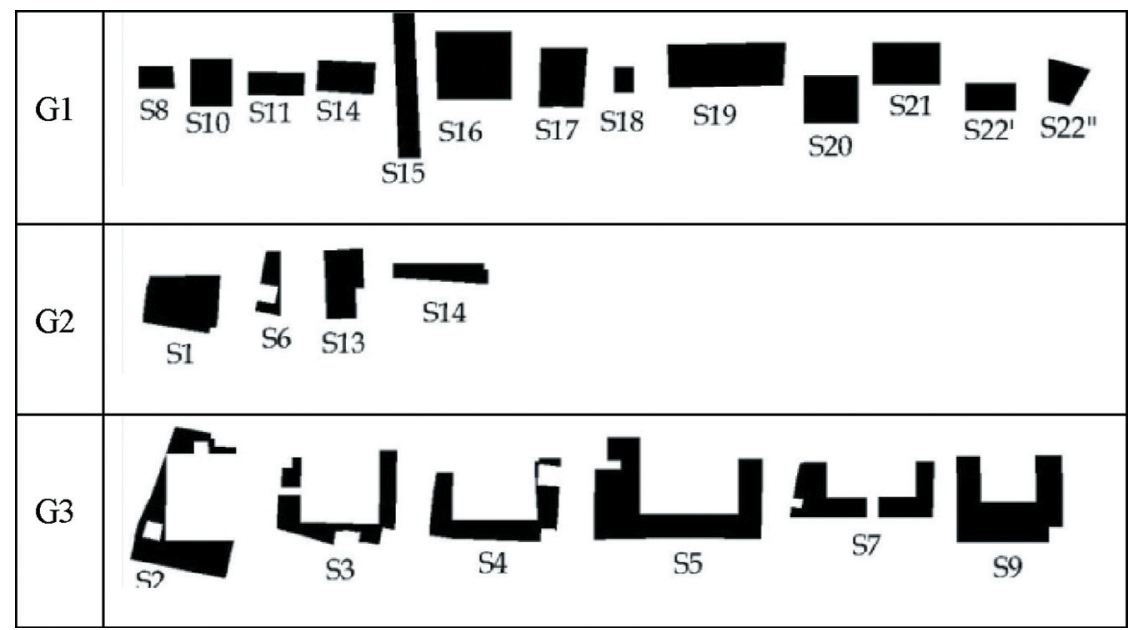

Table 3: Classification of forms of the segment C (courtyard).

For example, the study of the segment M (minaret) showed that this segment isn't omnipresent. Some specimens in the collection don't include minaret. Also we identified two classes of forms: square and octagonal.

In addition, the study of positions that occupy the segments $M$ showed that there are three groups of position: highly present positions (positions P4 and P3-4), moderately present positions (positions $\mathrm{Pa}$ and $\mathrm{P} 3$ ) and weakly present positions (P2-4 and P1-3).

Another example is of the segment $\mathrm{C}$ (courtyard): unlike the segment $\mathrm{M}$ (minaret), it seems to be an omnipresent segment; in fact, each specimen in the collection has a courtyard. Nevertheless, presence of two courtyards in the specimen S22 has been observed. Also the various forms have been classified into three types of families or classes as indicated in Table 3:

The segment $\mathrm{C}$ is highly present in position $\mathrm{P} 4$, moderately present in positions $\mathrm{P} 2$ and $\mathrm{P} 3$, possibly with continuities to intermediate positions (P2-4 and 3-4), and rarely present in position P1.

\section{CONCLUSION}

In this research, we were interested in the study of the spatial structure of the ancient Tunisian mosques. The study of 22 specimens allowed us to conclude that there is not a single model for the mosque in Tunisia but there is a morphological diversity characterized by a set of variable spatial configurations. Indeed, we identified classes of segments based on their forms and positions. While some positions are highly used, compared to others for a particular segment, this does not prevent the same segment to be located in other positions such as the minaret, which is most present in positions $\mathrm{P} 4$ and $\mathrm{P} 3-4$ but it is also present in position $\mathrm{Pa}, \mathrm{P} 3, \mathrm{P} 1-3$ and P2-4. The same was observed for forms; there is not a unique form for the minaret. It can be square or octagonal. This research is an exploratory study and the result provides us with an important knowledge about these mosques and encourages us to further deepen our research. 


\section{REFERENCES}

[1] Titus Burckhardt, T., L'art de l'islam: langage et signification, Sindbad, Paris, 306p., 1985.

[2] Creswell, K.A.C., Early Muslim Architecture, Oxford, 1932-1940.

[3] Grabar, O., The Formation of Islamic Art, Yale University Press, New Haven and London, 233p., 1973.

[4] Cherif, I. \& Allani Bouhoula, N., Tunis's new mosques constructed between 1975 and 1995: Morphological knowledge. Journal of Islamic Architecture, 3(3), pp. 115-126, 2015.

[5] Hoteit, A., Contemporary architectural trends and their impact on the symbolic and spiritual function of the mosque. International Journal of Current Research, 7(3), pp. 13547-13558, 2015.

[6] C.E. Bosworth, E. van Donzel, B. Lewis, Ch. Pellat et P. Heinrichs, Encyclopédie de l'Islam, Tome IV Mahk-Mid, Article Masdjid, édition Leiden E.J. Brill-Paris G.-P Mainsonneuve \& Larose S.A. pp. 629-699, 1991.

[7] Quran XXIV, 36. Pickthall Translation.

[8] Vogt-Goknil, U., Mosquée: Grands Courants de l'architecture islamique, chêne, Paris, $251 \mathrm{p} ., 1975$.

[9] Marçais, G., Tunis et Kairouan, Paris, 158p., 1937.

[10] Saladin, H., la mosquée de Sidi Okba à Kairouan, Paris, 1899.

[11] Saadaoui, A., Tunis ville Ottomane: trois siècles d'urbanisme et d'architecture, centre de la publication universitaire, Tunis, 538p., 2010. 